\title{
Fault Analysis of an Active LVDC Distribution Network for Utility Applications
}

\author{
Dong Wang \\ University of Strathclyde \\ Glasgow, UK \\ d.wang@strath.ac.uk
}

\author{
Abdullah Emhemed \\ University of Strathclyde \\ Glasgow, UK \\ abdullah.emhemed@strath.ac. \\ uk
}

\author{
Graeme Burt \\ University of Strathclyde \\ Glasgow, UK \\ graeme.burt@strath.ac.uk
}

\author{
Patrick Norman \\ University of Strathclyde \\ Glasgow, UK \\ patrick.norman@strath.ac.uk
}

\begin{abstract}
Low Voltage DC (LVDC) distribution systems are new promising technologies which can potentially improve the efficiency and controllability of existing $L V$ distribution networks. However, they do introduce new challenges under different fault conditions. Therefore, this paper investigates the performances of an active LVDC distribution network with local solar photovoltaics (PVs) and energy storages under different short-circuit faulted conditions. A typical UK LV distribution network energized by DC is used as a test network, and modeled using PSCAD/EMTDC. The LVDC is interfaced to the main AC grid using fully controlled two-level voltage source converter (VSC), and supplies DC and AC loads through DC/DC converter and DC/AC converter respectively. The response of an LVDC with such converters combination with different topologies and fault management capabilities are investigated through the simulation analysis.
\end{abstract}

Index Terms-- LVDC power distribution networks, AC/DC converter, DC/DC converter, fault analysis, DC protection, solar photovoltaic, energy storage.

\section{INTRODUCTION}

Low voltage direct current (LVDC) distribution systems have received wide interest as new component to improve the efficiency and performances of existing traditional distribution systems. As widely discussed in many publications [1]-[3], LVDC infrastructure is more suitable to connect distributed renewables such as solar photovoltaic and storage devices which inherently generate DC power, and directly supply DC loads without conversion losses. For other applications such as data centres, LVDC have already proven their benefits by delivering improved efficiency up to $28 \%$, reduced lifetime cost up to $36 \%$, and reduced floor space up to $33 \%$ [4]. However, implementing LVDC systems will present significant technical challenges [5], especially for DC fault detection, and isolation. DC fault currents normally have high $\mathrm{di} / \mathrm{dt}$, and this will make the fault detection and location more difficult. Also, the associated arcs are more aggressive than AC since DC current lacks zero crossing point [5]. Also, traditional $\mathrm{LV}$ protection schemes are not suitable for protecting LVDC system as longer time to operate is anticipated [6].

This will require good understanding of DC fault characteristics in order to design an effective DC protection scheme. This area has been investigated by a number of researches. For example, the work in [7] has characterised the performances of a passive LVDC distribution system under fault conditions and outlined the requirements for IEC 61660 improvement for such application. In [8] and [9], the fault characteristics of individual solar photovoltaic and battery energy storage are investigated. However, LVDC expects to host high penetration of PVs and battery storages in addition to supply different loads. This will make the LVDC network more complex due to multiple converters with different topologies and fault management capabilities. The previous work did not cover fault responses of such converters combination.

Therefore, the focus of this paper is on fault characterisation of an active LVDC distribution network for utility applications. The impacts of multiple converters with different topologies on LVDC performance under faulted condition are investigated. The outline of this paper is as follows. Section II introduces the benefits and challenges of LVDC distribution network. Section III discusses fault characteristics of different converter topologies. In section IV the test network is described. Section V investigates fault characteristics within different scenarios, and the simulated results are discussed in section VI. Finally, conclusions will be given in section VII.

\section{LVDC BENEFITS AND CHALLENGES}

LVDC distribution networks have many benefits over existing LVAC system, such as increased power transmission capacity, no skin effect, reduced conversion losses, and elimination of source synchronisation [10]-[12]. However, there are still some challenges remaining for DC distribution, especially for DC fault protections and safety. Recently a number of protection solutions have been proposed for different applications of DC in distribution systems. For example, fuse-based traditional overcurrent protection has been proposed for protecting LVDC distribution systems [13] and utilised in data center [14]. Other techniques such as directional and differential protections supported by communication and solid state breakers have been proposed in [15] and [16] for protecting LVDC distribution networks. Besides, more advanced signal processing tools based protections such as wavelet transform and artificial neural network analysis have been introduced for DC microgrids and MVDC shipboard power system respectively [17][18]. However, most of these techniques are expensive compared to 
AC solutions [19]. In addition, most of the aforementioned protection schemes are less effective for detecting high resistive fault currents, as for such type of faults there is no considerable variation in the current index. Ineffective and slow DC protections require higher rating elements. This will lead to the need for higher initial investment in LVDC. For example, the high cost of the converter at present is still higher than the cost saving from the conversion losses [20].

At an LVDC level, most of the developed protections schemes are based only on the coordination between the breakers. Within modern LVDC systems, the capabilities of converters could provide new opportunity for detecting and managing faults on the network [21]. This will require a good understanding of the impacts of converter combinations on fault responses of an active LVDC distribution networks. This will help to design the novel protection schemes and reduce the investment and cost.

\section{DC FAult Responses of DiffEREnt CONVERTERS TOPOLOGIES}

\section{A. AC/DC Converter}

In general, three types of converters can be used for converting AC to DC, and have been used to some level for LVDC systems. This includes two-level voltage source converter (VSC), neutral point clamped (NPC) converter, and modular multilevel converter (MMC). Each converter has different fault response.

The anticipated fault current paths of two-level converter are illustrated in Fig. 1. As shown in Fig. 1, the fault currents of a VSC interfaced system are defined as capacitor discharge (1), diode freewheeling (2), and grid contribution (3) [22]. The more details of mathematical expressions can be found in [22]. The filter capacitor will supply a high DC transient current at the start of the fault. After the capacitor is completely discharged, the freewheeling diodes will provide paths for fault currents supplied from the line inductor and the AC grid. The anti-parallel diodes must have enough rating to withstand such currents.

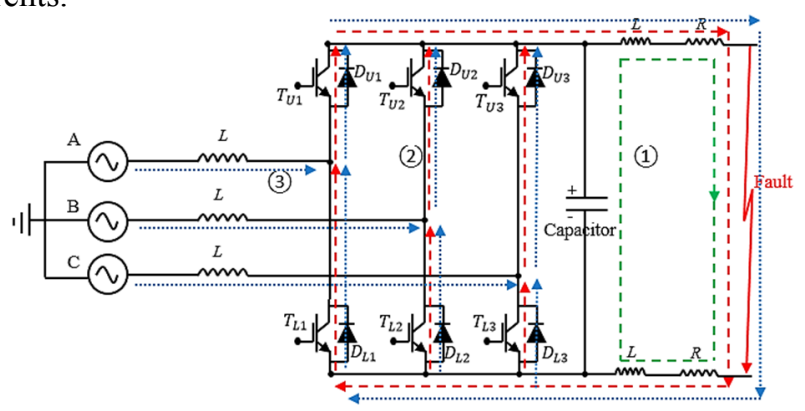

Fig. 1. Fault Current Paths of 2-level Voltage Source Converter

NPC converter has also been proposed for LVDC systems [23]. The simplified circuit is presented in Fig. 2. The NPC fault response is very similar to two-level VSC with limited fault management.

Unlike two-level and NPC VSCs, MMC is more complex, and has not been widely utilised in LVDC. MMC which can be half bridge (HB) or full bridge (FB). FB-MMC can provide fast fault current blocking. Simplified circuits of half bridge (HB) cell and full bridge cell are shown in Fig. 3. During the fault, HB-MMC could block the capacitor discharge, but AC supply still bypasses the capacitor to contribute the fault current. Regarding FB-MMC, both capacitor discharge and AC contribution can be interrupted as soon as IGBTs block.

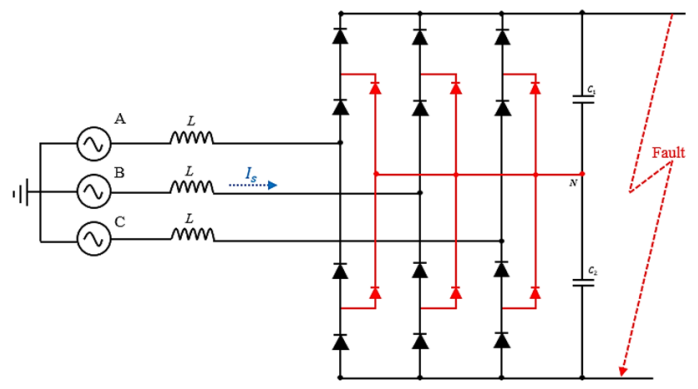

Fig. 2. Simplified Circuit of NPC Converter under DC fault condition

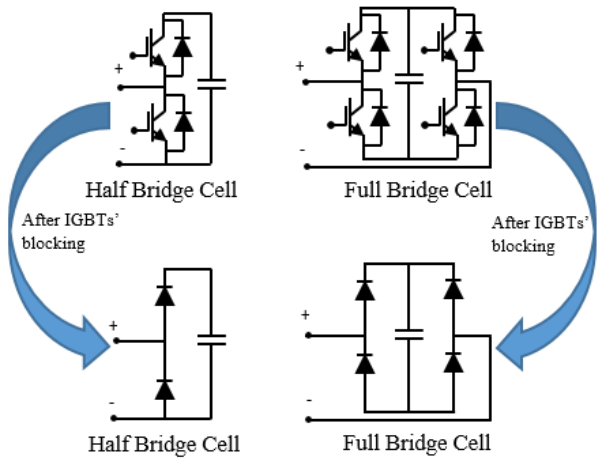

Fig. 3. Simplified Circuits of HB Cell and FB Cell [24]

\section{B. DC/DC Converter}

$\mathrm{DC} / \mathrm{DC}$ converter is an important component in LVDC systems as multiple voltage levels will be experienced. Fig. 4 shows a simplified circuit of basic DC/DC converter during the fault and blocking of the IGBTs'. The fault current blocking capability of DC/DC converter depends on the fault location. Only the fault current in buck direction can be blocked. In addition, the filter capacitor of this topology is free to discharge during the faults.

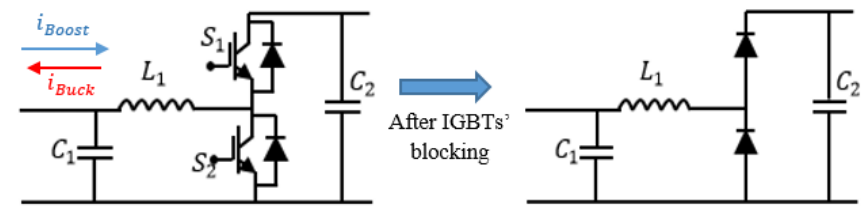

Fig. 4. Basic Topology of DC/DC Converter after IGBTs' Blocking [25]

In this paper, two-level VSC and basic DC/DC converter are selected as they are widely used in LVDC systems. The more details of test network configurations are introduced next.

\section{TEST NETWORK}

The test network is based on energising a typical UK distribution network using DC. The LVDC network is connected to the secondary substation of $11 \mathrm{kV} / 0.4 \mathrm{kV}$ 
transformer by two-level VSC as shown in Fig. 5, and modelled in PSCAD/EMTDC. The VSC provides voltage 750 $\mathrm{V}$ at the point of common coupling (PCC) [26]. Two main feeders (i.e. Line 1 and Line 2 as shown in Fig. 5) are modelled with resistor $(\mathrm{R}=0.164 \Omega / \mathrm{km})$ connected in series with an inductor $(\mathrm{L}=0.24 \mathrm{mH} / \mathrm{km})$ [7]. The length of each cable is assumed to be $1 \mathrm{~km}$.

The LVDC network supplies AC and DC loads through twolevel AC/DC VSC and DC/DC converter respectively. The AC customer is supplied by $230 \mathrm{~V}$ single phase voltage and hosts an AC source, and the DC customer by $200 \mathrm{~V}$. A $10 \mathrm{~kW} \mathrm{PV}$ and $7.8 \mathrm{kWh}$ battery storage are connected to the DC customer bus. The selection of $200 \mathrm{Vdc}$ for the DC customer is based on the DC safety consideration [27]. The models of the VSCs, battery, and PV with their associated control are developed as follows.

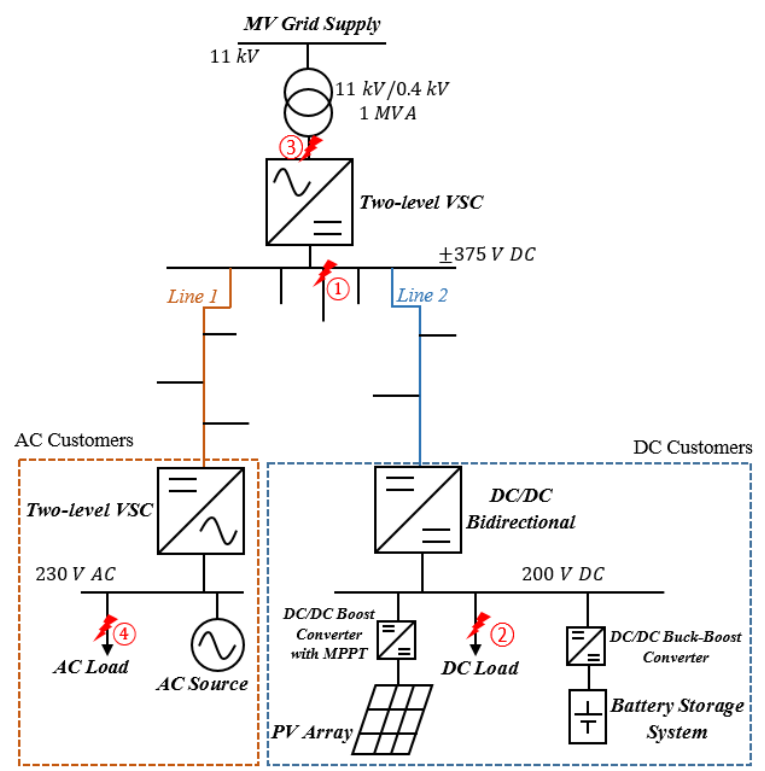

Fig. 5. Test Network Layout

\section{A. Model of Two-level VSC}

The two-level VSC which interfaced the LVDC network to the $\mathrm{AC}$ grid and the $\mathrm{AC}$ customer converter are modelled as a detailed two-level VSC model. The converter is fully controlled using the well-known pulse width modulation (PWM) vector control techniques as shown in Fig. 6 [28]. The $\mathrm{AC}$ customer VSC controls the active and reactive power (shown as APC and RPC in Fig. 6). The smoothing capacitor and line inductance associated with the VSCs are $C_{F}=3300 \mu F$ and $\mathrm{L}=3 \mathrm{mH}$ [29]. The grid tied $\mathrm{AC} / \mathrm{DC}$ converter is midpoint grounded.

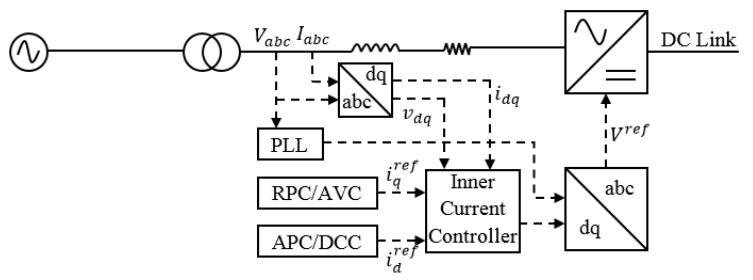

Fig. 6. Diagram of Vector Control [28]

\section{B. Model of DC/DC Bidirectional Converter}

The basic half-bridge DC/DC converter is used for interfacing the DC customer and modelled with voltage-mode control. The converter capacitors and inductor given as $C_{L}, C_{H}$, and $\mathrm{L}$ in Fig. 7 are chosen to be $680 \mu \mathrm{F}, 1500 \mu \mathrm{F}$, and $1 \mathrm{mH}$ respectively [30]. A simplified controller using the PWM technique is shown in Fig. 8 [31].

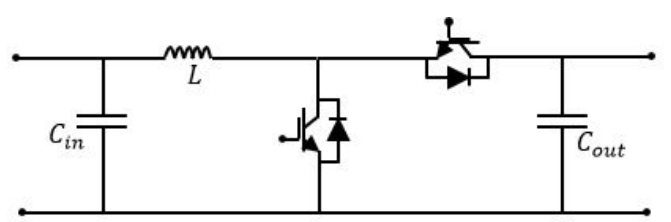

Fig. 7. Diagram of DC/DC Bidirectional Converter [30]

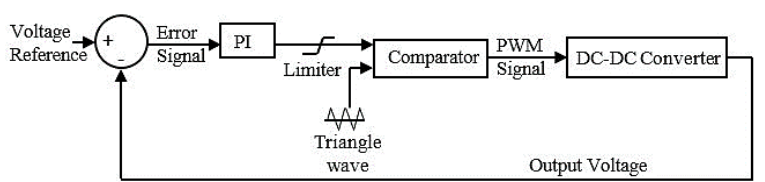

Fig. 8. Diagram of Voltage-mode Control [31]

\section{Model of PV with DC/DC Boost Converter}

A $10 \mathrm{~kW} \mathrm{PV}$ array is modelled following equations in [32], which is connected to the LVDC network via DC/DC boost converter with maximum power point tracking (MPPT) as shown in Fig. 9 [33]. The simulation parameters are established in Table I.

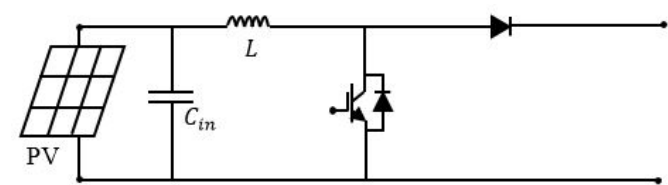

Fig. 9. Diagram of PV with MPPT based DC/DC Boost Converter

TABLE I

PV ARRAY AND BOOST CONVERTER SIMULATION PARAMETERS [33]

\begin{tabular}{|c|c|c|c|c|c|}
\hline & $\boldsymbol{I}_{\boldsymbol{s c}}$ & $\boldsymbol{V}_{\boldsymbol{m p p t}}$ & $\boldsymbol{P}_{\boldsymbol{m a x}}$ & $\boldsymbol{C}_{\boldsymbol{i n}}$ & $\boldsymbol{L}$ \\
\hline Value & $83 \mathrm{~A}$ & $135 \mathrm{~V}$ & $10 \mathrm{~kW}$ & $270 \mu \mathrm{F}$ & $0.001 \mathrm{H}$ \\
\hline
\end{tabular}

\section{Model of BESS with DC/DC Buck-Boost Converter}

A $7.8 \mathrm{kWh}$ Nickel-Metal Hybrid battery energy storage system (BESS) is created following the equations in [34], which is integrated to LVDC distribution network by DC/DC buck-boost converter as shown in Fig. 10 [35]. The control diagram is depicted in Fig. 8, and the relative parameters are listed in Table II.

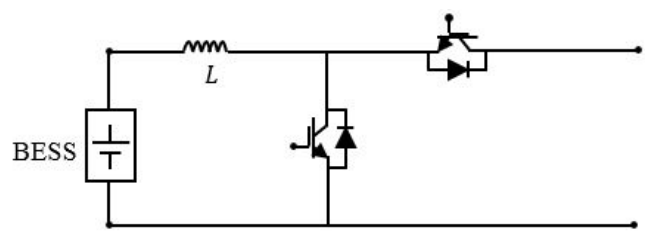

Fig. 10. Diagram of BESS with DC/DC Buck-Boost Converter

TABLE II

BES AND BUCK-BOOST CONVERTER SIMULATION PARAMETERS [34]

\begin{tabular}{|c|c|c|c|c|}
\hline & $\boldsymbol{I}_{\text {charge }}$ & $\boldsymbol{V}$ & $\boldsymbol{R}_{\text {int }}$ & $\boldsymbol{L}$ \\
\hline Value & $13 \mathrm{~A}$ & $140 \mathrm{~V}$ & $0.05 \Omega$ & $0.001 \mathrm{H}$ \\
\hline
\end{tabular}




\section{Simulation Studies}

This section investigates the performances of the test LVDC distribution network under the following three different fault conditions: DC pole to pole (P-P) fault, DC pole to ground (P$\mathrm{G})$ fault, and $\mathrm{AC}$ three-phase fault. The faults are applied at different locations as shown in Fig. 5. Each fault is initiated at time $=5 \mathrm{~s}$, and no protections are implemented. The response in each case is discussed as follows.

\section{A. Case 1: DC Pole to Pole Fault}

The DC pole to pole faults are implemented in location 1 and 2. In location 1, fault responses of grid tied $\mathrm{AC} / \mathrm{DC}$ converter is depicted in Fig. 11. In the transient period (capacitor discharge), as the fault loop of grid side lacks inductance, the filter capacitor releases its energy to the fault resistance that causes the current spike and the DC voltage drop.
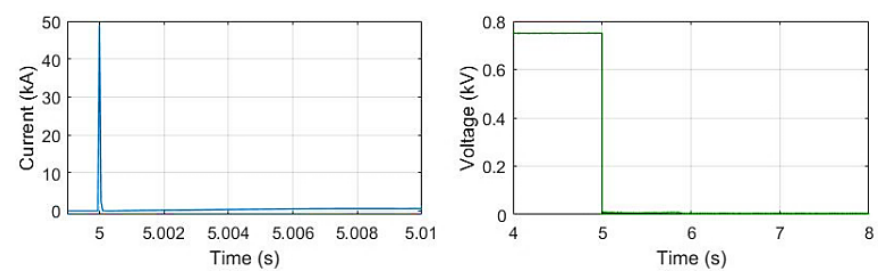

Fig. 11. Fault Responses of AC Grid Side VSC, Left: fault current; Right: DC grid voltage

The location 1 fault currents of DC customer are shown in Fig. 12. The current transient $(0.88 \mathrm{kA})$ is coming from the capacitor of $\mathrm{DC} / \mathrm{DC}$ bidirectional converter. In steady state, fault currents of DC customers are contributed by PV and BESS. In this case, PV array generates a constant fault current. Comparatively, fault current of BESS depending on the resistance of fault loop. As discussed in Section III, the basic half-bridge DC/DC converter is not capable of limiting the fault current from downstream and capacitor discharge.
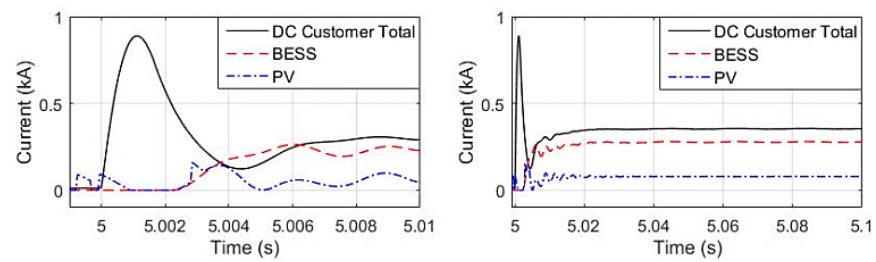

Fig. 12. Fault Current of DC Customers when DC P-P Fault in Location 1, Left: Transient Period; Right: Steady State

During the PCC P-P fault, there is an interaction between PV and BESS. Fig. 13 manifests the simplified circuit of a combination of PV and BESS under DC P-P fault condition. Compare to the individual contribution, fault current of BESS is reduced after connecting with PV as shown in equation (1). Here, $V_{B e s s}$ is the voltage of BESS, $I_{p v}$ is the fixed short circuit current of PV, $R_{\text {int }}$ is the internal resistance of BESS, and $R_{f}$ is the fault resistance.

$$
I_{B E S S}=\frac{V_{B e s s}-I_{p v} \times\left(2 R_{\text {line }}+R_{f}\right)}{\left(2 R_{\text {line }}+R_{f}\right)+R_{\text {int }}}
$$

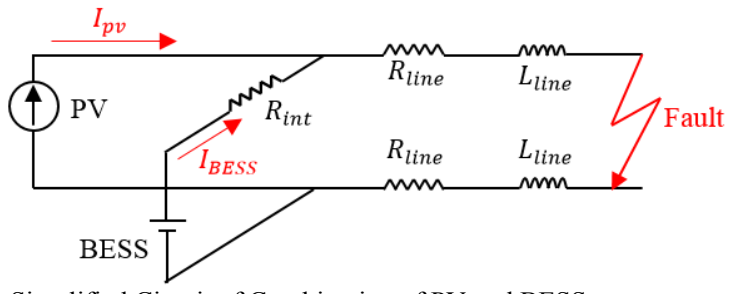

Fig. 13. Simplified Circuit of Combination of PV and BESS

The current responses of DC/AC converter with location 1 $\mathrm{P}-\mathrm{P}$ fault are depicted in Fig. 14. In the transient period, the filter capacitor discharge causes the current peak $(0.89 \mathrm{kA})$. This is closed to the DC customer fault transient as their faulted RLC circuits are similar. In steady state, fault current from AC customer is not series as DC customer. However, as introduced in Section III, the two-level VSC is unable to limit the fault current from AC source.
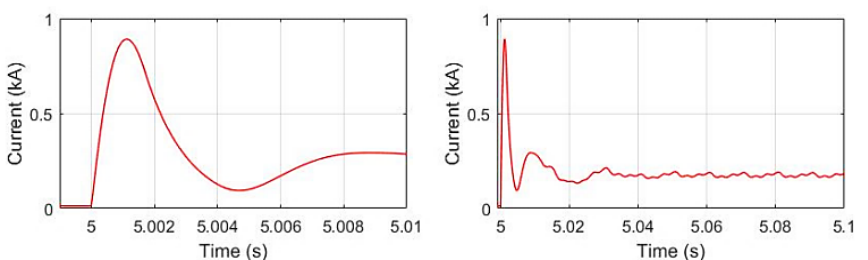

Fig. 14. Fault Current of AC Customers when DC P-P Fault in Location 1, Left: Transient Period; Right: Steady State

In location 2 P-P fault condition, the $\mathrm{DC} / \mathrm{DC}$ bidirectional converter is capable of limiting the fault current from upstream. Fig. 15 shows grid voltage and the steady state fault current of total, BESS, PV, and upstream from top to bottom respectively. The fault currents are mainly coming from PV and BESS since their integrated converters are unable to limit the fault current in the boost direction. Compare to the voltage responses in Fig. 11, in this scenario, the DC main grid voltage can be regulated after the transient drop.
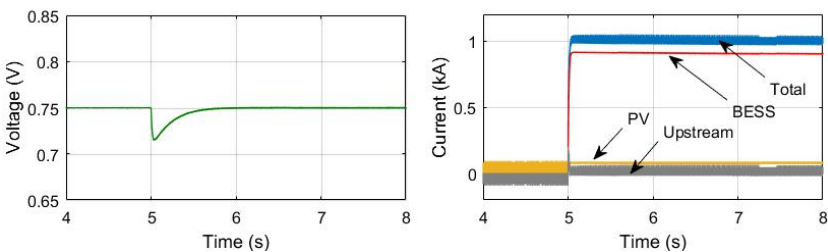

Fig. 15. Fault Responses with DC Load Side Fault, Left: DC grid voltage; Right: DC fault current.

\section{B. Case 2: DC Pole to Ground Fault}

DC P-G fault is implemented between the positive pole and ground only at location 1 . The DC fault currents are shown in Fig. 16. In the transient period, due to the midpoint grounding of the main AC/DC converter, P-G fault makes the top filter capacitor to start discharging. This has led to high transient current. After the capacitor is completely discharged, the negative pole will take full DC voltage (i.e. $750 \mathrm{Vdc}$ ) which may introduce equipment rating issue. In this case, it can be noticed as shown in Fig. 17 that the DC voltage can be regulated by the main VSC after the transient discharge of the top filter capacitor. 

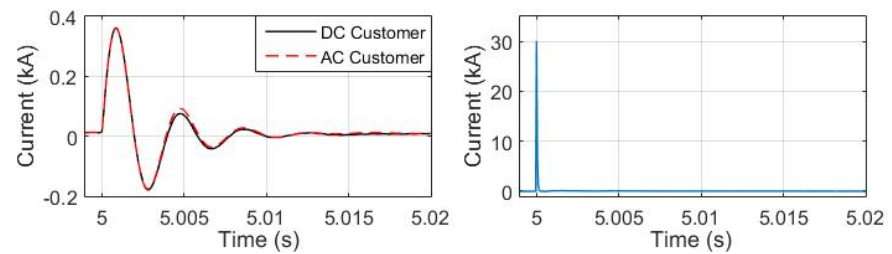

Fig. 16. Fault Currents of DC P-G fault in Location 1, Left: DC Customer and AC Customer; Right: AC grid
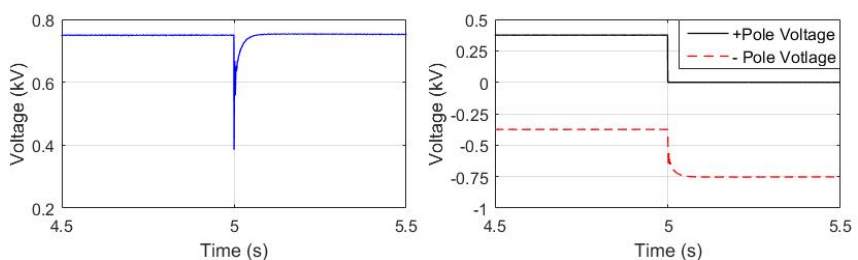

Fig. 17. Voltage Responses under PCC P-G fault condition, Left: DC grid voltage; Right: voltage of positive and negative poles to ground

\section{Case 3: AC Three-phase Fault}

In this case, three-phase fault are set in location 3 and location 4. Fig. 18 and Fig. 19 illustrates the fault responses in location 3. In normal operation, the DC customers send power to the $\mathrm{AC}$ grid, and $\mathrm{AC}$ customers receive the power from the $\mathrm{AC}$ grid. In the transient period, as no power sending from $\mathrm{AC}$ grid, the DC grid voltage collapses. Since the current from DC side is limited by the VSC, DC grid voltage can be maintained.
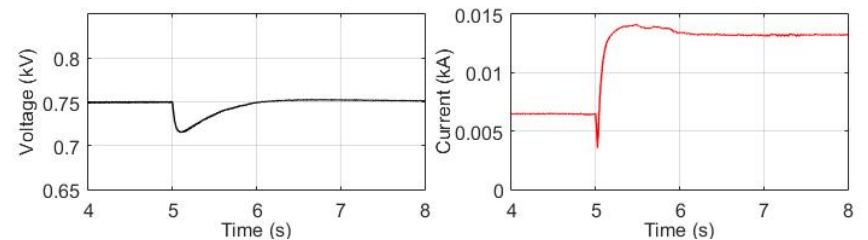

Fig. 18. Fault Responses under AC Grid Three-phase Fault Condition, Left: DC grid voltage; Right: RMS fault current from LVDC.

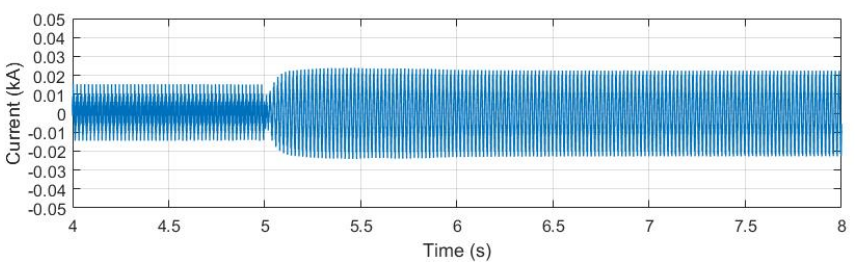

Fig. 19. Fault Current from LVDC in Location 3

In location 4, fault responses are depicted in Fig. 20 and Fig. 21. Compare to the fault responses in Fig 15 and Fig. 18, the voltage shows the different characteristics. When the fault happens, the fault current from DC side is limited that causes the power increase in the DC side. This leads to the voltage increase in the transient period. By the VSC control, DC grid voltage can be regulated.
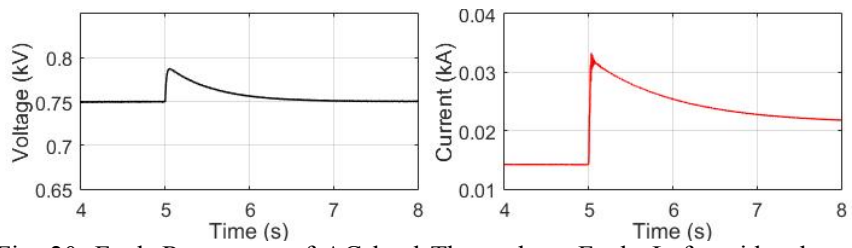

Fig. 20. Fault Responses of AC load Three-phase Fault, Left: grid voltage; Right: RMS fault current from DC LVDC.

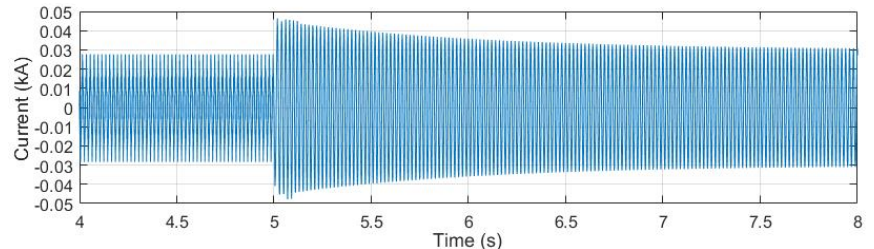

Fig. 21. Fault Current from LVDC in Location 4

\section{Discussion OF Simulated RESUlts}

Comparing DC P-P faults at location 1 and 2, the fault at location 1 is more severe. The P-P fault at location 1 makes the entire LVDC to experience large voltage drop as shown in Fig. 11. In this case, the upstream and downstream converters cannot limit the fault current contributions from the grid and customer sides. As for the DC P-P fault at location 2, the fault current contribution from the upstream is limited by the DC/DC bidirectional converter. This has limited the impact of the fault on the LVDC voltage profiles on the main feeder and on the point of common coupling. Such performance can allow the loads and generators connected to adjacent unfaulted feeders to ride through such faults.

In the condition of DC P-G fault, and with neutral mid-point grounding configuration, only transient DC fault current is experienced and the steady state current is insignificant. In this case, the healthy pole can still operate with the full P-P DC voltage.

In the case of the AC three-phase fault on both locations 3 and 4 , the fault current can be easily limited by the two-level VSCs controllers. This has allowed the LVDC to experience low levels of fault currents with limited post-fault voltages issues.

To sum up, the performance of an LVDC with a combination of multiple converters under a faulted condition will depend on the fault type and location. The LVDC is very sensitive to faults on the DC side (i.e. on the main bus or on one of the main feeders). High transient and steady state fault currents can be experience on the whole LVDC network in such cases. Whilst, the impacts of faults at end users interfaced by $\mathrm{DC} / \mathrm{DC}$ converter or a simple two-level VSCs are local due to the fault limitation by these converter only for such type of faults. Such features will require fast protection scheme at an LVDC system level to protect against upstream DC faults and coordinated with downstream converters for protecting against local faults on the load sides. The other option is to use fault-tolerant converters with blocking capabilities and good level of coordination to achieve fault detection, location and interruption within the required protection operating time.

\section{CONCLUSIONS}

This paper has provided a detailed model of an active LVDC distribution network with a combination of different converters for utility application, and investigated its performance under different AC and DC fault conditions. The simulation results have shown that upstream DC pole to pole faults in comparison 
to $\mathrm{DC}$ pole to ground and AC side faults are the most extreme and can cause complete voltage collapse on the LVDC network. The converters are defenceless for such fault, and they are only capable of limiting fault currents flowing to the $\mathrm{AC}$ sides or local faults isolated by a DC/DC converter from the grid. Enabling an active LVDC with multiple converters for delivering good performance for distribution systems will require fast DC protection scheme which can be coordinated with the converters (taking the advantage of converters with fault-tolerant and current blocking capabilities) to provide an effective and fast protection for equipment and personnel.

\section{REFERENCES}

[1] E. R. Diaz, J. C. Vasquez, J. M. Guerrero, "Intelligent DC Homes in Future Sustainable Energy Systems," IEEE Consumer Electronics Magazine, Vol:5, Iss: 1, Jan 2016

[2] J. J. Justo, F. Mwasilu, J. Lee, J. W. Jung, "AC-microgrids versus DCmicrogrids with distributed energy resources: A review," Renewable and Sustainable Energy Review, vol. 24, pp. 387-405, 21 Mar 2013.

[3] A. T. Elsayed, A. A. Mohamed, O. A. Mohammed, "DC Microgrids and distribution systems: An overview," Electric Power Systems Research, vol. 119, pp. 407-417, 16 Oct 2014.

[4] G. AlLee, and W. Tschudi, "380 Vdc Brings Reliability and Efficiency to Sustainable Data Centers," IEEE Power and Energy Magazine, Vol. 10, Iss. 6, Dec 2012.

[5] T. Dragicevic, X, Lu, J. C. Vasquez, J. M. Guerrero, "DC MicrogridsPart II: A Review of Power Architectures, Applications, and Standardization Issues," IEEE Transactions on Power Electronics, Vol. 31, Iss. 5, 04 August 2015.

[6] A. Emhemed, G. Burt, "Protection Analysis for Plant Rating and Power Quality issues in LVDC Distribution Power Systems," IEEE Power \& Energy Society General Meeting, 26-30 July 2015.

[7] A. Emhemed, G. Burt, "THE EFFECTIVENESS OF USING IEC61660 FOR CHARACTERING SHORT-CIRCUIT CURRENT OF FUTURE LOW VOLTAGE DC DISTRIBUTION NETWORKS," in $22^{\text {nd }}$ International Conference on Electricity Distribution (CIRED), 10-13 June 2013.

[8] "Technical Application Paper No. 14 Faults in LVDC microgrids with front-end converters," www.abb.com, 30 June 2015.

[9] M. Carminati, E. Ragaini, E. Tironi, "DC and AC ground fault analysis in LVDC microgrids with energy storage system," in $15^{\text {th }}$ Environment and Electrical Engineering International Conference, 10-13 June 2015.

[10] H. Pugliese, and M. Von Kannewurff, "Discovering DC: A Primer on DC Circuit Breaker, Their Advantages, and Design," IEEE Industry Applications Magazine, Vol. 19, No. 5, September- October 2013.

[11] I. Patrao, E. Figueres, G. Garcera, R. G. Medina, "Microgrid architectures for low votalge distributed generation," Renewable and Sustainable Energy Reviews, 27 Nov 2014.

[12] F. M. Martinez, A. S. Miralles, M. Rivier, "A literature review of Microgrids: A functional layer based classification," Renewable and Sustainable Energy Review, 3 May 2016.

[13] P. Salonen, P. Nuutinen, P. Peltoniemi, J. Partanen, "Protection Scheme for an LVDC Distribution System," in $20^{\text {th }}$ CIRED Electricity Distribution International Conference, 8-11 June 2009.

[14] P. Hu, "Design and Specification for Safe and Reliable Battery Systems for Large UPS," White paper 207, Schneider, 10 Dec 2014.

[15] A. Emhemed, G. Burt, "An Advanced Protection Scheme for Enabling an LVDC Last Mile Distribution Network," IEEE Transaction on Smart Grid, Vol. 5, No. 5, 08 Sep 2014.

[16] J. Park, and J. Candelaria, "Fault Detection and Isolation in Low-Voltage DC-Bus Microgrid System," IEEE Transaction on Power Delivery, Vol. 28, No. 2, 21 Mar 2013.

[17] K. A. Saleh, A. Hooshyar, E. F. Saadany, "Hybrid Passive-Overcurrent Relay for Detection of Faults in Low-Voltage DC Grids," IEEE Transaction on Smart Grid, 29 Sep 2015.

[18] W. Li, A. Monti, F. Ponci, "Fault Detection and Classification in Medium Voltage DC Shipboard Power System with Wavelets and Artificial
Neural networks," IEEE Transaction on Instrumentation and Measurement, Vol. 63, Iss. 11, 09 Oct 2014

[19] L. Mackay, T. Hailu, L. R. Elizondo, and P. Bauer, "Towards a DC Distribution System-opportunities and challenges," ICDCM, IEEE, 10 June 2015.

[20] A. Shivakumar, M. Normark, "Household DC network: State of the art and future prospects," INSIGHT E, September 2015.

[21] J. Yang, "Protection Issue Discussion of DC Network Development: Circuit Breaker or Fault-Tolerant Converter," in $11^{\text {th }}$ Development in Power System Protection International Conference, 23-26 April 2012.

[22] J. Yang, J. E. Fletcher, and J. O'Reilly, "Short-Circuit and Ground Fault Analyses and Location in VSC-Based DC Network Cables," IEEE Trans. Ind. Electron., Vol 59, No. 10, pp. 3827-3837, Oct 2012.

[23] J. Cho, J. H. Kim, W. Chae, H. J. Lee, and J. Kim, "DESIGN AND CONSTRUCTION OF KOREAN LVDC DISTRIBUTION SYSTEM FOR SUPPLYING DC POWER TO CUSTOMER," $23^{R D}$ International Conference on Electricity Distribution, 18 June 2015.

[24] R. Zeng, L. Xu, L. Yao, "An improved modular Multilevel Converter with DC Fault Blocking Capability," in IEEE PES General Meeting| Conference \& Exposition, 27-31 July 2014.

[25] X. Wang, M. Yue, E. Muljadi, "Modeling and Control Design for an Integrated Solar Generation and Energy Storage System with a RideThrough Capability," IEEE Energy Conversion Congress and Exposition, 15-20 Sep 2012.

[26] J. Karppanen, T. Kaipia, P. Nuutinen, A. Lana, P. Peltoniemi, A. Pinomaa, A. Mattsson, J. Partanen, J. Cho, and J. Kim, "Effect of Voltage Level Selection on Earthing and Protection of LVDC Distribution Systems," $A C$ and DC Power Transmission, $11^{\text {th }}$ IET International Conference, 12 Feb 2015.

[27] D. J. Becker, and B. J. Sonnenberg, "400 Vdc Power Distribution: Overcoming the Challenges," Intelec 2010, 10 June 2010.

[28] G. P. Adam, "Voltage Source Converter: modulation, modelling, control and applications in power systems," CreateSpace Independent Publishing Platform, 11 Sep 2014.

[29] J. H. Lee, H. J. Kim, B. M. Han, Y. S. Jeong, H. S. Yang, H. J. Cha, "DC Micro-Grid Operational Analysis with a Detailed Simulation Model for Distributed Generation", IEEE Energy Conversion Congress and Expositin, 12-16 Sep 2010.

[30] Y. Du, X. zhou, S. Bai. S. Lukic, A. Huang, "Review of non-isolated bidirectional DC-DC converters for plug-in hybrid electric vehicle charge station application at municipal parking decks," in $25^{\text {th }}$ Applied Power Electronics Conference and Exposition, 21-25 Feb 2010.

[31] M. H. Rashid, "Power electronics handbook: devices, circuits and applications," Academic press, 2010.

[32] R. Gupta, G. Gupta, D. Kastwar, A. Hussain, and H. Ranjan, "Modeling and Design of MPPT Controller for a PV Module using PSCAD/EMTDC," in IEEE PES Innovation Smart Grid Technologies Conference Europe, 13 Oct 2010

[33] M. Z. Daud, A. Mohamed, and M. A. Hannan, “An Optimal Control Strategy for DC Bus Voltage Regulation in Photovoltaic System with Battery Energy Storage," Scientific World journal, Vol. 2014, 2014.

[34] O. Tremblay, L. A. Dessaint, and A.I. Dekkiche, "A Generic battery Model for the Dynamic Simulation of hybrid Electric Vehicles," in IEEE Vehicle Power and Propulsion Conference, pp. 284-289, 12 Sep 2007.

[35] M. Yilmaz, P. Krein, "Review of Battery Charger Topologies, Charging Power Levels, and infrastructure for Plug-In Electric and Hybrid Vehicles," IEEE Transactions on Power Electronics, Vol. 28, No. 5, May 2013. 